\title{
ANALISIS PENGARUH SUKU BUNGA DAN DEPOSITO TERHADAP LABA PADA PT. BANK MANDIRI (PERSERO) CABANG TANJUNG BALAI KARIMUN TAHUN 2015-2018
}

\author{
Fauzan Haqiqi, Aulia Berliana, Yusmalina, Tegor \\ Program Studi Akuntansi, Universitas Karimun
}

Email : fauzanhaqiqi.1986@gmail.com aulia.berliana@gmail.com yusmalina8484@ gmail.com tigor.belitong@gmail.com

\begin{abstract}
Abstrak
Bank merupakan lembaga keuangan atau perusahaan yang bergerak di bidang keuangan yang menyediakan berbagai jasa keuangan. Kegiatan penghimpun dana merupakan mengumpulkan dana masyarakat dalam bentuk simpanan, tabungan dan deposito. Tujuan penelitian ini adalah untuk mengetahui seberapa besar Pengaruh Suku Bunga dan Deposito terhadap Laba ada PT. Bank Mandiri (Persero) cabang Tanjung Balai Karimun. Metode Penelitian kuantitatif yaitu penelitian yang menekankan pada pengujian teori melalui pengukuran variabel-variabel penelitian dengan angka dan melakukan analisis data dengan prosedur statistik. Hasil Penelitian: Hipotesis 1 : Diterima yaitu Suku Bunga secara parsial memiliki pengaruh signifikan terhadap Laba pada Bank Mandiri Cabang Tanjung Balai Karimun. Hal ini ditunjukkan dengan nilai signifikansi 0.010 kurang dari taraf nyata 0.05 atau $(0.010<0.05)$. Hipotesis 2: Diterima yaitu Deposito secara parsial memiliki pengaruh signifikan terhadap Laba pada Bank Mandiri Cabang Tanjung Balai Karimun. Hal ini ditunjukkan dengan nilai signifikansi 0.000 kurang dari taraf nyata 0.05 atau $(0.000<0.05)$. Hipotesis3 : Diterima, yaitu secara simultan menunjukan bahwa Suku Bunga dan Deposito berpengaruh signifikan terhadap Laba. Hal ini ditunjukkan dengan nilai signifikan kurang dari taraf nyata 0.05 atau $(0.00<0.05)$ dan memiliki nilai $\mathrm{F}$ hitung sebesar 52.096.
\end{abstract}

Kata Kunci : Bank, Suku Bunga, Deposito, Laba.

\section{PENDAHULUAN}

Bank merupakan lembaga keuangan atau perusahaan yang bergerak di bidang keuangan yang menyediakan berbagai jasa keuangan. Bank saat ini telah menjadi sarana yang mampu menghimpun dan menyalurkan dana masyarakat secara efektif dan efisien ke arah peningkatan taraf hidup rakyat. Kegiatan menyalurkan dana merupakan kegiatan utama yang dilakukan bank untuk memberikan jasa bagi nasabah. Kegiatan penghimpun dana merupakan mengumpulkan dana masyarakat dalam bentuk simpanan, tabungan dan deposito

Deposito yang merupakan produk simpanan yang ditawarkan perbankan mampu menjadi alternatif dalam melakukan investasi keuangan bagi masyarakat atau perusahaan karena memiliki return yang cukup tinggi dibandingkan jenis simpanan dana bank lainnya. Produk bank yang berasal dari jenis simpanan deposito pada umumnya memiliki biaya tertinggi dibandingkan dengan sumber dana lainnya dan bersifat lebih stabil dibandingkan dengan sumber dana seperti tabungan dan giro. Dalam hal deposito, PT. Bank Mandiri Cabang Karimun menerapkan suku bunga sesuai dengan kondisi perkembangan BI rate serta jumlah simpanan yang telah ada. PT. Bank Mandiri Cabang Karimun dalam menarik minat nasabah mampu memberikan jaminan berupa penerapan suku bunga yang mampu bersaing dengan bank lainnya. Penerapan tingkat suku bunga tersebut juga disesuaikan oleh berbagai faktor, salah satu faktor tersebut yaitu berapa besar target dalam jumlah dana simpanan yang ingin dihimpun oleh bank. PT. Bank Mandiri Cabang Karimun mengharapkan dapat memenuhi 
kebutuhan akan jumlah dana yang dihimpun dengan penerapan suku bunga yang bersaing dengan bank lainnya.

Tabel 1. Deposito, suku bunga dan laba PT. Bank Mandiri Cabang Tanjung Balai Karimun Tahun 2015-2018

\begin{tabular}{|c|c|c|c|}
\hline \multirow{2}{*}{ TAHUN } & \multicolumn{3}{|c|}{$\begin{array}{c}\text { JANGKA 12 BULAN } \\
\text { (dalam jutaan rupiah) }\end{array}$} \\
\cline { 2 - 4 } & Suku Bunga & Deposito & Laba \\
\hline 2015 & $5,25 \%$ & Rp. 200.431.272,- & $74,354,939$ \\
\hline 2016 & $5,00 \%$ & Rp. 233.617.801,- & $88,391,970$ \\
\hline 2017 & $4,75 \%$ & Rp. 230.860.731,- & $102,244,204$ \\
\hline 2018 & $4,25 \%$ & Rp. 247.286.664,- & $117,035,185$ \\
\hline
\end{tabular}

Produk deposito PT. Bank Mandiri Cabang Karimun dengan tingkat suku bunga terdiri dari beberapa periode bulan, yaitu Periode 1 bulan bunga depositonya 4,50\% $(<\mathrm{Rp}$. 100.000.000,-), periode 3 bulan depositonya 5,50\% (> Rp. 100.000.0000,- $<1 \mathrm{M}$ ), periode 6 bulan depositonya 4,75\% ( $>2 \mathrm{M}<5 \mathrm{M}$ ), Periode 24 bulan 4,75\% ( > 5M). Penelitian ini menggunakan laporan keuangan neraca Bank Mandiri dari jumlah simpanan berjangka per tahun. Berdasarkan perkembangan deposito pada Bank Mandiri cabang Tanjung Balai Karimun pada periode tahun 2015-2018 diketahui mengalami peningkatan yaitu tahun 2015 sebesar Rp. 200.431.277,-. Tahun 2016 sebesar Rp. 233.647.801,-. Tahun 2017 sebesar Rp. 230.860.731,-- dan Tahun 2018 sebesar Rp. 247.286.661,--

\section{TINJAUAN LITERATUR}

\section{Suku Bunga}

Sebagai bank sentral, BI memiliki satu tujuan tunggal, yaitu mencapai dan memelihara nilai rupiah. Kestabilan ini bisa mengandung 2 aspek, yakni : 1) Kestabilan nilai mata uang pada barang dan jasa. 2) Kestabilan nilai mata uang pada mata uang negara lain.

Kasmir (2012), bunga juga dapat diartikan sebagai harga yang harus dibayar kepada nasabah (yang memiliki simpanan) dengan yang harus dibayar oleh nasabah kepada bank (nasabah yang memperoleh pinjaman). Sedangkan suku bunga adalah rasio dari bunga terhadap jumlah pinjaman. Samuelson dan Nordhaus (2004), suku bunga adalah jumlah uang yang dibayarkan per unit waktu yang disebut sebagai presentase dari jumlah yang dipinjamkan.

\section{Suku Bunga Simpanan}

Mishkin (2010) menyatakan bahwa suku bunga (interest rate) adalah biaya pinjaman atau harga yang dibayarkan untuk dana pinjaman tersebut. Maria (2016) menyebutkan bahwa suku bunga adalah harga dari meminjam uang untuk menggunakan daya belinya. Persentase dari pokok utang yang dibayarkan sebagai imbal jasa bunga) dalam suatu periode tertentu disebut suku bunga. Berdasarkan definisinya tersebut, maka jenis bunga bisa dibagi menjadi : 1) Suku bunga kredit (lending facility), yakni jenis bunga yang digunakan dalam urusan pinjam meminjam. Klasifikasi suku bunga kredit bisa dibagi berdasarkan sifat dan perhitungannya, yakni: Suku bunga tetap (fixed), yang berarti tingkatannya tidak berubah selama masa kredit. 2) Suku bunga mengambang (floating), yang artinya tingkatnya berubahubah mengikuti suku bunga pasar selama masa kredit. Ada juga klasifikasi suku bunga kredit 
yang berdasarkan perhitungannya, yaitu : a) Suku bunga flat, yang dihitung dari jumlah awal pokok pinjaman dan dibagikan secara proporsional berdasarkan tenor kredit. b) Suku bunga efektif, yang dihitung dari sisa jumlah pokok pinjaman sehingga besaran bunga yang dibayarkan akan turun seiring sisa masa pembayaran. c) Suku bunga anuitas, yang merupakan gabungan antara suku bunga flat dan efektif. Artinya, bunga dihitung berdasarkan sisa pokok pinjaman namun dibagikan secara proporsional berdasarkan tenor.

Dalam teori Kasmir (2012) terdapat dua macam bunga yang diberikan kepada nasabahnya, yaitu: a) Bunga Simpanan, merupakan harga beli yang harus dibayar bank kepada nasabah pemilik simpanan. Bunga ini diberikan sebagai rangsangan atau balas jasa, kepada nasabah yang menyimpan uangnya di bank. Sebagai contoh jasa giro, bunga tabungan, dan bunga deposito. b) Bunga Pinjaman, merupakan bunga yang diberikan kepada pemimpin (debitur) atau harga jual yang harus dibayar oleh nasabah peminjam kepada bank. Bagi bank bunga pinjaman merupakan harga jual dan contoh harga jual adalah bunga kredit.

\section{Deposito}

Deposito merupakan salah satu jenis simpanan dana yang ditawarkan oleh bank sebagai lembaga keuangan. Deposito berbeda dengan jenis simpanan lain seperti tabungan, karena imemiliki jangka waktu dalam hal penyimpanan dana di bank. Deposito memiliki karakteristik tersendiri dibandingkan jenis simpanan lain dan menjadi salah satu sumber pemasukan dana bagi bank karena mampu menarik minat masyarakat karena adanya bunga return yang menjadi daya tarik. Maka dari itu perlu dikemukakan beberapa definisi dari deposito, yaitu: 1). Pernyataan dari Taswan (2010), menyatakan bahwa deposito merupakan jenis simpanan dana bagi masyarakat atau pihak ketiga yang penarikannya hanya dapat dilakukan pada waktu yang sesuai dengan ketentuan berdasarkan perjanjian antara bank dengan pihak yang bersangkutan. 2). Pernyataan dari Dietrich dan Wanzenried yang dikutip dalam jurnal Lailatul Mukaromah (2015), menyatakan bahwa deposito merupakan sumber pendanaan yang mendasar untuk pembiayaan suatu bank. Jika deposito meningkat maka profitabilitas bank juga meningkat, tetapi hal itu tergantung sejauh mana pihak bank mampu mengkonversi kewajiban deposito ke dalam dalam bentuk kredit, sehingga bank iakan mendapatkan penghasilan dari deposito tersebut.

Jenis deposito yang ada di bank dan ditawarkan pada masyarakat adalah : 1). Deposito berjangka adalah deposito yang diterbitkan menurut jangka waktu tertentu. Jangka waktu deposito mulai dari 1,2,3,6,12,18, sampai dengan 24 bulan. Deposito berjangka diterbitkan atas nama baik perorang maupun lembaga. 2). Sertifikat deposito adalah deposito yang diterbitkan dengan jangka waktu 2,3,6, dan 12 bulan. Sertifikat deposito diterbitkan atas tunjuk dalam bentuk sertifikat, di dalam sertifikat deposito tidak tertulis nama seseorang atau badan hukum tertentu. Disamping itu sertifikat deposito dapat diperjual belikan pada pihak lain.3). Deposit on call adalah deposito yang berjangka waktu minimal 7 hari dan paling lama kurang dari 1 bulan. Diterbitkan atas nama dan biasanya dalam jumlah yang besar misalnya 50 juta rupiah. Bunga deposito di hitung mulai dari penyetoran dana sampai jatuh tempo. Perhitungan tiap bulan sesuai dengan jumlah hari sebenarnya dari bulan yang bersangkutan, dan jumlah hari bunga dalam satu iahun di hitung sebanyak 365 hari. Dengan diperhitungan besarnya bunga deposito yang di terima deposan adalah sebagai berikut :

Bunga deposito $=$ Nominal deposito $\mathrm{x}$ suku bunga $\mathrm{x}$ hari (365)

Penarikan bunga dapat dilakukan sesuai dengan perjanjian sewaktu pembukaan rekening, yaitu : a). Dapat ditarik tunai setiap bulan; b). Dapat ditarik setelah deposito jatuh tempo; c). Dapat 
ditambahkan ke nominal deposito setelah jatuh tempo jangka waktunya; d). Dapat dipindah bukukan kerekening tabungan atau rekening giro; e). Dapat dipindah bukukan kerekening pemilik di bank lain.

\section{Laba}

Stice (2009) laba adalah pengambilan atas investasi kepada pemilik. Hal ini mengukur nilai yang dapat diberikan oleh entitas kepada investor dan entitas masih memiliki kekayaan yang sama dengan posisi awalnya. Berdasarkan beberapa definisi di atas, dapat disimpulkan bahwa laba merupakan kinerja perusahaan yang di ukur dari pengurangan antara pendapatan dan beban-beban perusahaan yang terjadi pada suatu periode tertentu.

Samryn (2012), menyatakan bahwa pengertian laba adalah sebagai berikut: "Laba merupakan sumber dana internal yang dapat diperoleh dari aktivitas normal perusahaan yang tidak membutuhkan biaya ekstra untuk penyimpanan dan penggunaannya. Wild dan Subramanyam (2014), menyatakan bahwa pengertian laba adalah Laba (earnings) atau laba bersih (net income) mengindikasikan profitabilitas perusahaan. Laba mencerminkan pengembalian kepada pemegang ekuitas untuk periode bersangkutan, sementara pos-pos dalam laporan merinci bagaimana laba didapat. Kusuma (2012), pertumbuhan laba dipengaruhi oleh perubahan komponen-komponen dalam laporan keuangan misalnya perubahan penjualan, perubahan harga pokok penjualan, perubahan beban operasi, perubahan beban bunga dan perubahan pajak penghasilan.

\section{METODE PENELITIAN}

\section{Variabel Penelitian}

Adapun variabel independen adalah Suku Bunga (X1) dan Deposito (X2) dan variabel dependen adalah Laba (Y). Penelitian ini untuk menguji pengaruh Variabel X (suku bunga dan deposito) terhadap $\mathrm{Y}$ (Laba). Sedangkan untuk menganalisis pengaruh masing-masing variabel menggunakan teknik analisis regresi linear berganda. 1). Suku Bunga (X1), Suku bunga adalah biaya pinjaman atau harga yang dibayarkan untuk dana pinjaman tersebut (biasanya dinyatakan sebagai persentase per tahun) (Mishkin, 2008). 2). Deposito (X2), merupakan jenis simpanan dana bagi masyarakat atau pihak ketiga yang penarikannya hanya dapat dilakukan pada waktu yang sesuai dengan ketentuan berdasarkan perjanjian antara bank dengan pihak yang bersangkutan (Taswan, 2010). 3). Laba (Y), merupakan sumber dana internal yang dapat diperoleh dari aktivitas normal perusahaan yang tidak membutuhkan biaya ekstra untuk penyimpanan dan penggunaannya (Samryn, 2012).

\section{Populasi dan Sampel}

Populasi dalam penelitian ini mencakup seluruh data perkembangan jumlah dana simpanan deposito yang ada pada PT. Bank Mandiri Cabang Tanjung Balai Karimun. Populasi dalam penelitian ini adalah semua deposan baik perorangan ataupun lembaga menyimpan dananya pada PT. Bank Mandiri Cabang Tanjung Balai Karimun.

Untuk penentuan sampel dalam penelitian ini, penulis hanya mengambil beberapa data tingkat suku bunga dan jumlah dana deposito berjangka selama 4 tahun yang sudah terdata pada laporan keuangan Bank Mandiri Cabang Tanjung Balai Karimun pada OJK (Otoritas Jasa Keuangan) periode tahun 2015-2018. Untuk pengambilan sampel dalam penelitian ini, penulis menggunakan teknik pengambilan sampel berupa sampel data untuk 4 tahun terakhir dengan pertimbangan waktu tertentu yang dapat mewakili.

\section{Analisis Data}


1). Analisis Regresi Linier Berganda, Regresi merupakan suatu metode dalam statistic yang dapat digunakan untuk melihat ada atau tidaknya hubungan (hubungan kausal atau sebab akibat) dan ditampilkan dalam bentuk model sistematis atau persamaan. 2). Uji Hipotesis, dalam penelitian ini menggunakan : a). Uji t (uji parsial), melakukan pengujian terhadap koefisien regresi secara parsial, pengujian ini dilakukan untuk mengetahui signifikan secara parsial antara variabel independen terhadap variabel dependen dengan mengasumsikan bahwa variabel independen lain dianggap konstan. (t-test) hasil perhitungan ini selanjutnya dibandingkan dengan $\mathrm{t}$ tabel dengan menggunakan tingkat kesalahan 0,05 . Kriteria yang digunakan :

$$
\begin{array}{r}
\text { Diterima jika nilai } \leq \text { atau nilai sig }>\alpha \\
\text { Ditolak jika nilai } \geq \text { atau nilai sig }<\alpha
\end{array}
$$

Bila terjadi penerimaan Ho maka dapat disimpulkan bahwa tidak terdapat pengaruh signifikan, sedangkan bila Ho di tolak artinya terdapat pengaruh yang signifikan. Rancangan pengujian hipotesis statistik ini untuk menguji ada tidaknya pengaruh antara variabel independent yaitu suku bunga (X1), deposito (X2), dan laba (Y), dengan hipotesis dalam penelitian ini adalah :

Ho: $\beta=0$ : tidak terdapat pengaruh yangisignifikan

Ha : $\beta \neq 0$ : terdapat pengaruh yang signifikan

\section{Uji F (Pengujian Secara Simultan)}

Uji $F$ adalah pengujian terhadap koefisien regresi secara simultan. Pengujian ini dilakukan untuk mengetahui pengaruh semua variabel independen yang terdapat di dalam model secara bersama-sama (simultan) terhadap variabel dependen. Uji $\mathrm{F}$ dalam penelitian ini digunakan untuk menguji signifikasi pengaruh Suku Bunga dan Deposito Terhadap Laba secara simultan. F hasil perhitungan ini dibandingkan dengan yang diperoleh dengan menggunakan tingkat resiko atau signifikan level 5\% atau dengan degree freedom $=\mathrm{k}(\mathrm{n}-\mathrm{k}-1)$ dengan kriterian sebagai berikut : Ditolak jika $>$ atau nilai sig $<\alpha$ dan Diterima jika $<$ atau nilai sig $>\alpha$. Jika terjadi penerimaani, maka dapat diartikan tidak berpengaruh signifikan model regresi berganda yang diperoleh sehingga mengakibatkan tidak signifikan pula pengaruh dari variabel-variabel bebas bebas secara simultan terhadap variabel terikat. Adapun yang menjadi hipotesis nol dalam penelitian ini adalah sebagai berikut :

$$
\mathrm{H} 0: \beta 1=\beta 2=\beta 3=0: \text { tidak berpengaruh signifikan }
$$

Ha : $\beta 1 \neq \beta 2 \neq \beta 3 \neq 0$ : terdapat pengaruh yang signifikan

Penetapan tingkat signifikansi Pegujian hipotesis akan dilakukan dengan menggunakan tingkat signifikansi sebesar $0,05(\alpha=0)$ atau tingkat keyakinan sebesar 0,95 .

\section{Koefisien Determinasi}

Koefisien determinasi merupakan untuk mengetahui kesesuaian atau ketepatan antara nilai dugaan atau garis regresi dengan data sampel. Apabila nilai koefisien korelasi sudah diketahui, maka untuk mendapatkan koefisien determinasi dapat diperoleh dengan kriteria untuk analisis koefisien determinan adalah: Jika Kd mendeteksi nol, maka pengaruh variabel independent terhadap variabel dependent lemah, Jika Kd mendeteksi satu, maka pengaruh variabel independet terhadap variabel dependent kuat. 


\section{HASIL PENELITIAN DAN PEMBAHASAN}

Adapun teknik analisis data yang digunakan dalam penelitian ini adalah analisis regresi linier sederhana, uji asumsi klasik (normalitas dan heteroskedastisitas), hipotesisuji t (uji signifikan secara parsial) dan uji koefisien determinasi R2.

A. Uji Regresi Linier Berganda

Tabel 2. Regresi Linier Berganda

Coefficients $^{\mathrm{a}}$

\begin{tabular}{|c|c|c|c|c|c|}
\hline \multirow[t]{2}{*}{ Model } & \multicolumn{2}{|c|}{ Unstandardized Coefficients } & $\begin{array}{l}\text { Standardized } \\
\text { Coefficients }\end{array}$ & & \\
\hline & B & Std. Error & Beta & $\mathrm{t}$ & Sig. \\
\hline $1 \quad$ (Constant) & -1.480 & 5.532 & & -2.676 & .019 \\
\hline Suku Bunga & 3.427 & 1.146 & .279 & 2.991 & .010 \\
\hline Deposito & .432 & .047 & .864 & 9.274 & .000 \\
\hline
\end{tabular}

a. Dependent Variable: Laba

$$
\begin{gathered}
Y=a+b 1 X 1+b 2 X 2 \\
Y=-1.480+(3.427 X 1)+(0.432 X 2)
\end{gathered}
$$

1) Dari penjabaran diatas dapat disimpulkan bahwa nilai konstanta sebesar -1.480 menunjukan nilai Laba sebelum di pengaruhi oleh variabel suku bunga dan deposito adalah positif.

2) Koefisien $b 1=3.427$ menunjukkan peningkatan 1 skor suku bunga akan menurunkan laba sebesar 3.427 dengan asumsi variabel-variabel bebas lainnya konstan.

3) Koefisien b2 $=0.432$ menunjukkan peningkatan 1 skor pengalaman kerja akan meningkatkan kinerja karyawan sebesar 0,432 dengan asumsi variabel-variabel bebas lainnya konstan. Koefisien bernilai positif artinya terjadi pengaruh positif antara pengalaman kerja dengan kinerja karyawan, semakin berpengalaman maka semakin meningkat kinerja karyawannya.

\section{Uji Hipotesis}

Uji t ( Uji Parsial)

\begin{tabular}{|c|c|c|c|c|}
\hline \multicolumn{5}{|c|}{ Coefficients ${ }^{a}$} \\
\hline \multicolumn{2}{|c|}{ Model } & \multirow{3}{*}{$\frac{\text { Standardized Coefficients }}{\text { Beta }}$} & \multirow[b]{3}{*}{$\mathrm{t}$} & \multirow[b]{3}{*}{ Sig. } \\
\hline & & & & \\
\hline & & & & \\
\hline \multirow[t]{3}{*}{1} & (Constant) & & -2.676 & .019 \\
\hline & SUku BUnga & .279 & 2.991 & .010 \\
\hline & Deposito & .864 & 9.274 & .000 \\
\hline \multicolumn{5}{|c|}{ a. Dependent Variable: Laba } \\
\hline
\end{tabular}

\section{Tabel 3. Uji Parsial}

Berdasarkan tabel di atas dari analisis data menunjukan bahwa nilai probabilitas t-hitung :

1) Variabel suku bunga (variabel X1) memiliki nilai signifikansi sebesar 0.010. Oleh karena nilai signifikansi lebih kecil dari 0.05 maka hal tersebut menunjukan bahwa suku bunga berpengaruh terhadap laba pada Kantor Bank cabang Mandiri Tanjung Balai Karimun berarti H1 Diterima. 
2) Variabel deposito (variabel X2) memiliki ilia signifikansi sebesar 0.000. Oleh karena nilai signifikansi lebih kecil dari 0.05 maka hal tersebut menunjukan bahwa deposito berpengaruh terhadap laba pada Kantor Bank cabang Mandiri Tanjung Balai Karimun berarti H2 diterima.

Uji F ( Uji Simultan)

Tabel 4. Uji Simultan

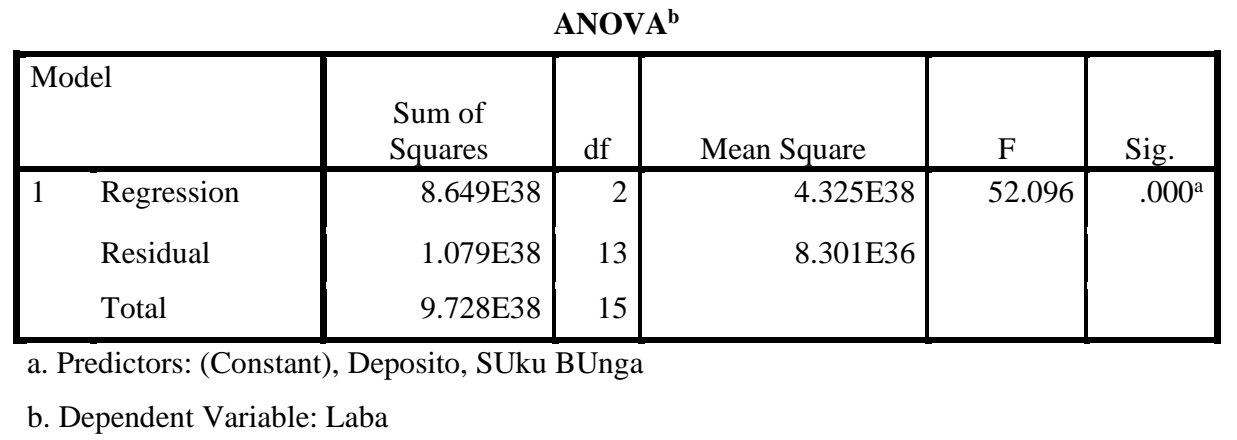

Hasil analisis data mengenai pengaruh suku bunga dan deposito terhadap laba menunjukan nilai sig 0.000. Nilai sig jika dibandingkan dengan sig $\alpha=0.05$, maka nilai sig lebih kecil dari sig $\alpha$, yaitu $0.000<0.05$. Hasil tersebut dapat disimpulkan bahwa hipotesis penelitian ini memiliki pengaruh suku bunga dan deposito terhadap laba.

\section{Koefesien Determinasi}

Tabel 5. Uji Determinan

Model Summary ${ }^{b}$

\begin{tabular}{|l|r|r|r|r|}
\hline Model & $\mathrm{R}$ & R Square & Adjusted R Square & $\begin{array}{c}\text { Std. Error of } \\
\text { the Estimate }\end{array}$ \\
\hline 1 & $.943^{\mathrm{a}}$ & .889 & & 2.881 \\
\hline
\end{tabular}

a. Predictors: (Constant), Deposito, SUku BUnga

b. Dependent Variable: Laba

Tabel di atas menunjukan nilai R square sebesar 0.889. Hasil R square menunjukan bahwa besarnya pengaruh suku bunga dan deposito terhadap laba sebesar $88.9 \%$ adapun sisanya $11.1 \%$ dipengaruhi faktor lain di luar penelitian ini.

\section{KESIMPULAN}

Berdasarkan uraian-uraian yang telah peneliti paparkan terhadap data peneliti yang telah terkempul yang kemudian diolah, mengenai pengaruh tingkat suku bunga dan deposito terhadap laba pada Bank Mandiri Cabang Tanjung Balai Karimun, maka penelitian dapat mengambil beberapa kesimpulan sebagai jawaban atas pertanyaan-pertanyaan yang terdapat pada identifikasi masalah yang menjadi acuan dasar dari maksud dan tujuan penelitian ini antara lain sebagai berikut, terdapat pengaruh signifikan dan positif antara tingkat suku bunga dan deposito terhadap laba pada Bank Mandiri Cabang Tanjung Balai Karimun "diterima”. Berdasarkan penelitian yang telah dilakukan oleh penulis, adapun kesimpulan yang dapat diambil yaitu sebagai berikut : 
Hipotesis 1 : Diterima yaitu Suku Bunga secara parsial memiliki pengaruh signifikan terhadap Laba pada Bank Mandiri Cabang Tanjung Balai Karimun. Hal ini ditunjukkan dengan nilai signifikansi 0.010 kurang dari taraf nyata 0.05 atau $(0.010<0.05)$.

Hipotesis 2: Diterima yaitu Deposito secara parsial memiliki pengaruh signifikan terhadap Laba pada Bank Mandiri Cabang Tanjung Balai Karimun. Hal ini ditunjukkan dengan nilai signifikansi 0.000 kurang dari taraf nyata 0.05 atau $(0.000<0.05)$. 


\section{DAFTAR PUSTAKA}

Irham. Fahmi. 2015. Pengantar Manajemen Keuangan Teori dan Soal Jawab. Alfabeta. Bandung

Indrayenti Susanti, 2015. Pengaruh Tingkat Suku Bunga Simpanan Terhadap Jumlah Deposito pada PT. Bank Rakyat Indonesia (Persero) Tbk. Cabang Liwa. Universitas Bandar Lampung.Vol.6 No.1.

Ismail. 2010. Manajemen Perbankan, Prenada Media Group. Jakarta Iswardono. 2006. Ekonomi Mikro.UPP AMP YKPN. Yogyakarta Hasibuan, Malayu. 2012. Manajemen Sumber Daya manusia. PT Bumi. Aksara. Jakarta Kasmir. 2012. Bank dan Lembaga Kuangan Lainnya. PT. Raja Grafindo. Persada. Jakarta Mishkin, Frederic S. 2010. Ekonomi Uang, Perbankan, dan Pasar Keuangan. Edisi 8. Salemba Empat : Jakarta.

Sugiyono. 2010. Metode Penelitian Kuantitatif, Kualitatif Dan R\&D. Alfabeta. Bandung.

Stice, Earl K, James D Stice dan Fred Skousen, 2009 Akuntansi Keuangan Menengah, Edisi 16, Buku 2. Edisi Bahasa Indonesia. Terjemah Oleh Ali Akbar. PT. Salemba Empat: Jakarta.

Haqiqi, F. (2019). PENGARUH KEDISIPLINAN TERHADAP KINERJA PEGAWAI UNIVERSITAS KARIMUN. Khazanah Ilmu Berazam, 2 (3 Sept), 377 - 384. Retrieved from https://ejournal.ymbz.or.id/index.php/KIB/article/view/98.

Haqiqi, F., Santika, M., \& Yusmalina. (2021). ANALISIS PENGARUH REALISASI PENERIMAAN BEA MASUK TERHADAP TARGET PENERIMAAN BEA MASUK (PADA KANTOR PENGAWASAN DAN PELAYANAN BEA CUKAI TIPE MADYA B TANJUNG BALAI KARIMUN PERIODE 2017-2019). JURNAL CAFETARIA, 2(1), 48-61. https://doi.org/10.51742/akuntansi.v2i1.282.

Joko, S. D., dan Tegor. (2019). National security of investment climate: a case study in the South Sulawesi region of indonesia. Russian Journal of Agricultural and SocioEconomic Sciences, 85(1).

Tegor., dan Umar, Husein. (2017). Compensation analysis in relationship moderation between transformational leadership style and work environment on the employee performance. Russian Journal of Agricultural and Socio-Economic Sciences, 71(11).

Tegor, T., Yusmalina, Y., \& Haqiqi, F. (2021). PENERAPAN STANDAR AKUNTANSI DAN KUALITAS APARATUR TERHADAP LAPORAN KEUANGAN PEMERINTAH DAERAH (Studi Kasus pada Dinas Pekerjaan Umum dan Penataan Ruang Kabupaten Karimun). JURNAL CAFETARIA, 2(1), 13-24.

Yusmalina, Y., Tegor, T., Haqiqi, F., Rosady, R. E., \& Azura, N. (2021). Comparative Analysis of Staretegi Traditional Market and Modern Markets of Consumer Valuation. International Journal of Multicultural and Multireligious Understanding, 8(11), 18-25. 